\title{
Toward a Framework for Understanding Forces that Contribute to or Reinforce Racial Inequality
}

\section{Citation}

Wilson, William Julius. 2009. Toward a Framework for Understanding Forces that Contribute to or Reinforce Racial Inequality. Race and Social Problems 1(1):3-11.

\section{Published Version}

http://dx.doi.org/10.1007/s12552-009-9004-4

\section{Permanent link}

http://nrs.harvard.edu/urn-3:HUL.InstRepos:4778369

\section{Terms of Use}

This article was downloaded from Harvard University's DASH repository, and is made available under the terms and conditions applicable to Open Access Policy Articles, as set forth at http:// nrs.harvard.edu/urn-3:HUL.InstRepos:dash.current.terms-of-use\#OAP

\section{Share Your Story}

The Harvard community has made this article openly available.

Please share how this access benefits you. Submit a story.

Accessibility 


\title{
Toward a Framework for Understanding Forces that Contribute to or Reinforce Racial Inequality ${ }^{*}$
}

By

\author{
William Julius Wilson \\ Harvard University
}

$\mathbf{k}$

In this paper I seek to reframe current debates around structural and cultural explanations concerning the interconnectedness of race and poverty in the United States. In recent decades discussions of race, inequality and family hardship have consolidated around two opposing perspectives, namely those who support a mainly structural explanation for chronic hardship versus those who espouse cultural explanations. While underscoring the structural origins of black poverty in the United States, I seek to resituate how we think about and research racial disadvantage by proposing a framework that acknowledges the convergence of social, economic, political and cultural forces in contemporary society. In so doing, I hope to spark greater interest and dialogue in the research and policy arenas around a more holistic approach to poverty alleviation.

\section{Understanding the Impact of Structural Forces}

Two types of structural forces contribute directly to racial group outcomes such as differences in poverty and employment rate: social acts and social processes. 'Social acts' refers to the behavior of individuals within society. Examples of social acts are stereotyping;

* This paper is based on my new book, More than Just Race: Being Black and Poor in the Inner City. New York: W.W. Norton, 2009. 
stigmatization; discrimination in hiring, job promotions, housing, and admission to educational institutions - as well as exclusion from unions, employers' associations, and clubs — when any of these are the act of an individual or group exercising power over others.

'Social processes' refers to the "machinery" of society that exists to promote ongoing relations among members of the larger group. Examples of social processes that contribute directly to racial group outcomes include laws, policies, and institutional practices that exclude people on the basis of race or ethnicity. These range from explicit arrangements such as Jim Crow segregation laws and voting restrictions to more subtle institutional processes, such as school tracking that purports to be academic but often reproduces traditional segregation, racial profiling by police that purports to be about public safety but focuses solely on minorities, and redlining by banks that purports to be about sound fiscal policy but results in the exclusion of people of color from home ownership. In all of these cases, ideologies about group differences are embedded in organizational arrangements.

However, many social observers who are sensitive to and often outraged by the direct forces of racism, such as discrimination and segregation, have paid far less attention to those political and economic forces that indirectly contribute to racial inequality. ${ }^{1}$ I have in mind political actions that have an impact on racial group outcomes, even though they are not explicitly designed or publicly discussed as matters involving race, as well as impersonal economic forces that reinforce long-standing forms of racial inequality. These structural forces are classified as indirect because they are mediated by the racial groups' position in the system of social stratification (the extent to which the members of a group occupy positions of power, influence, privilege and prestige). In other words, economic changes and political decisions may have a greater adverse impact on some groups than on others simply because the former are more 
vulnerable as a consequence of their position in the social stratification system. These indirect structural forces are often so massive in their impact on the social position and experiences of people of color that they deserve full consideration in understanding the factors leading to differential outcomes along racial lines.

Take, for instance, impersonal economic forces, which sharply increased joblessness and declining real wages among many poor African Americans in the last several decades. As with all other Americans, the economic fate of African Americans is inextricably connected with the structure and functioning of a much broader, globally influenced modern economy. In recent years, the growth and spread of new technologies and the growing internationalization of economic activity have changed the relative demand for different types of workers. The wedding of emerging technologies and international competition has eroded the basic institutions of the mass production system and eradicated related jobs in manufacturing in the United States. In the last several decades, almost all of the improvements in productivity have been associated with technology and human capital, thereby drastically reducing the importance of physical capital and natural resources. The changes in technology that are producing new jobs are making many others obsolete.

Although these trends tend to benefit highly educated or highly skilled workers, they have contributed to the growing threat of job displacement and eroding wages for unskilled workers. This development is particularly problematic for African Americans who have a much higher proportion of workers in low-skilled jobs than whites. As the late black economist Vivian Henderson argued three decades ago, racism put blacks in their economic place, but changes in the modern economy make the place in which they find themselves more and more precarious. ${ }^{2}$ 
The workplace has been revolutionized by technological changes that range from mechanical development like robotics, to advances in information technology like computers and the internet. While even educated workers are struggling to keep pace with technological changes, lower-skilled workers with less education are falling behind with the increased use of information-based technologies and computers and face the growing threat of job displacement in certain industries. ${ }^{3}$ To illustrate, in 1962 the employment-to-population ratio - the percentage of adults who are employed-was 52.5 percent for those with less than a high school diploma, but by 1990 it had plummeted to 37.0 percent. By 2006 it rebounded slightly to 43.2 percent, possibly because of the influx of low-skilled Latino immigrants in low-wage service-sector jobs. ${ }^{4}$

In the new global economy, highly educated, well-trained men and women are in demand, as illustrated most dramatically in the sharp differences in employment experiences among men. Compared to men with lower levels of education, collegeeducated men spend more time working, not less. ${ }^{5}$ The shift in the demand for labor is especially devastating for those low-skilled workers whose incorporation into the mainstream economy has been marginal or recent. Even before the economic restructuring of the nation's economy, low-skilled African Americans were at the end of the employment line, often the last to be hired and the first to be let go.

The computer revolution is a major reason for the shift in the demand for skilled workers. Even "unskilled" jobs such as fast food service require employees to work with computerized systems, even though they are not considered skilled workers. Whereas only one-quarter of US workers directly used a computer on their jobs in 1984, by 2003 that figure had risen to more than half $(56.1 \%)$ the workforce. ${ }^{6}$ According to the 
economist Alan Krueger, "The expansion of computer use can account for one-third to two-thirds of the increase in the payoff of education between 1984 and 1993 [in the U.S.]." Krueger gives two reasons for this expansion: First, even after a number of background factors such as experience and education are taken into account, those who use computers at work tend to be paid more than those who do not. Second, the industries with the greatest shift in employment toward more highly skilled workers are those in which computer technology is more intensively used.

The shift in the United States away from low-skilled workers can also be related to the growing internationalization of economic activity, including increased trade with countries that have large numbers of low-skilled, low-wage workers. ${ }^{8}$ Two developments facilitated the growth in global economic activity: (1) advances in information and communication technologies, which enabled companies to shift work to areas around the world where wages for unskilled work are much lower than in the "first world;" and (2) the expansion of free trade, which reduced the price of imports and raised the output of export industries. But increasing imports that compete with labor-intensive industries (for example, apparel, textile, toys, footwear, and some manufacturing) hurts unskilled labor. ${ }^{9}$

Since the late 1960s international trade has accounted for an increasing share of the U.S. economy, and, beginning in the early 1980s, imports of manufactured goods from developing countries have soared. ${ }^{10}$ According to economic theory, the expansion of trade with countries that have a large proportion of relatively unskilled labor will result in downward pressure on the wages of low-skilled Americans because of the lower prices of the goods those foreign workers produce. Because of the concentration of low-skilled 
black workers in vulnerable labor-intensive industries (e.g., 40 percent of textile workers are African American even though blacks are only about 13 percent of the general population; this overrepresentation is typical in many low-skill industries), developments in international trade are likely to further exacerbate their declining labor market experiences. $^{11}$

Note that the sharp decline in the relative demand for low-skilled labor has had a more adverse effect on blacks than on whites in the United States because a substantially larger proportion of African Americans are unskilled. Indeed, the disproportionate percentage of unskilled African Americans is one of the legacies of historic racial subjugation. Black mobility in the economy was severely impeded by job discrimination as well as failing segregated public schools, where per-capita expenditures to educate African American children were far below amounts provided for white public schools. ${ }^{12}$ While the more educated and highly trained African Americans, like their counterparts among other racial groups, have very likely benefited from the shifts in labor demand, those with lesser skills have suffered. Although the number of skilled blacks (including managers, professionals, and technicians) has increased sharply in the last several years, the proportion of those who are unskilled remains large. This is because the black population, burdened by cumulative experiences of racial restrictions, was overwhelmingly unskilled just several decades ago. ${ }^{13}$ As urban economies have transformed from goods production to more of a digitized, information-focused "virtual" workplace, black central city residents with little or no education beyond high school see their access to employment increasingly restricted to low-paying jobs in the service sector. 
The economic situation for many African Americans has now been further weakened because they tend not only to reside in communities that have higher jobless rates and lower employment growth—-for example, places like Detroit or Philadelphia-but also they lack access to areas of higher employment growth. ${ }^{14}$ As the world of corporate employment has relocated to America's suburban communities, over twothirds of employment growth in metropolitan areas has occurred in the suburbs, ${ }^{15}$ many of the residents of our inner-city ghettos are physically isolated from places of employment and socially isolated from the informal job networks that are often essential for job placement.

The growing suburbanization of jobs means that labor markets today are mainly regional, and long commutes in automobiles are common among blue-collar as well as white-collar workers. For those who cannot afford to own, operate, and insure a private automobile the commute between inner-city neighborhoods and suburban job locations becomes a Herculean task. ${ }^{16}$ For example, Boston welfare recipients found that only 14 percent of the entry-level jobs in the fast-growth areas of the Boston metropolitan region could be accessed via public transit in less than one hour. And in the Atlanta metropolitan area, fewer than one-half of the entry level jobs are located within a quarter mile of a public transit system. ${ }^{17}$ To make matters worse, many inner-city residents lack information about suburban job opportunities. In the segregated inner-city ghettos, the breakdown of the informal job information network magnifies the problems of job spatial mismatch - the notion that work and people are located in two different places. ${ }^{18}$

Although racial discrimination and segregation exacerbate the labor-market problems of the low-skilled African Americans, many of these problems are currently 
driven by shifts in the economy. Between 1947 and the early 1970s, all income groups in America experienced economic advancement. In fact, poor families enjoyed higher growth in annual real income than did other families. In the early 1970s, however, this pattern began to change. American families in higher income groups, especially those in the top 20 percent, continued to enjoy steady income gains (adjusted for inflation), while those in the lowest 40 percent experienced declining or stagnating incomes. This growing disparity in income, which continued through the mid-1990s, was related to a slowdown in productivity growth and the resulting downward pressure on wages. ${ }^{19}$

Then, beginning in late 1995 productivity began to surge, averaging 2.6 percent annual growth and reaching an astonishing 6.4 percent annual rate in the last quarter of 1999. Given the rate of productivity growth, a rising gross domestic product, and sustained low unemployment rates, the most optimistic scenario at the end of the $20^{\text {th }}$ century was that this new economy would eventually produce rates of family economic progress similar to those of the 1950s and 1960s.

From 1996 to 2000 real wage growth — that is, wages adjusted for inflation--was quite impressive, especially for low-wage workers. The ranks of the long-term joblessdefined in the US economy as those in the labor market who have been out of work for more than six months - plummeted from almost 2 million in 1993 to just 637,000 in 2000. The unemployment rate of high school dropouts declined from almost 12 percent in 1992 to less than 7 percent in 2000 . The unemployment rate among blacks declined to 7.3 percent, the lowest ever recorded since the Bureau of Labor Statistics began compiling comparable statistics in 1972. 
More than any other group, low-skilled workers depend upon a strong economy, particularly a sustained tight labor market— that is, one in which there are ample jobs for all applicants. In a slack labor market—a labor market with high unemploymentemployers can afford to be more selective in recruiting and granting promotions. With fewer jobs to award, they can inflate job requirements, pursuing workers with college degrees, for example, in jobs that have traditionally been associated with high schoollevel education. In such an economic climate discrimination rises and disadvantaged minorities, especially those with low levels of literacy, suffer disproportionately.

Conversely, in a tight labor market job vacancies are numerous, unemployment is of short duration, and wages are higher. Moreover, in a tight labor market the labor force expands because increased job opportunities not only reduce unemployment but also draw in workers who previously dropped out of the labor force altogether during a slack labor market period. Thus, in a tight labor market the status of all workers - including disadvantaged minoritiesimproves.

Just as blacks suffered greatly during the decades of growing separation between haves and have-nots, they benefited considerably from the incredible economic boom the country enjoyed in the last half of the 1990 s. $^{20}$ This period saw not only substantially reduced unemployment and concentrated poverty (areas where 40 percent or more of the residents live in poverty) for blacks and other groups, but sharply increased the earnings of all low-wage workers as well.

Undoubtedly, if the robust economy could have been extended for several more years, rather than coming to an abrupt halt in 2001, joblessness and concentrated poverty in inner cities 
would have declined even more. ${ }^{21}$ Nonetheless, many people concerned about poverty and rising inequality have noted that productivity and economic growth are only part of the picture.

Thanks to the Clinton-era economic boom, in the latter 1990s there were signs that America's rising economic inequality that began in the early 1970s was finally in remission. Nonetheless, worrisome questions were raised by many observers at that time: Will this new economy eventually produce the sort of progress that prevailed in the two and a half decades prior to 1970 - a pattern in which a rising tide did indeed lift all boats? Or would the government's social and economic policies prevent us from duplicating this prolonged pattern of broadly equal economic gains? In other words, the future of ordinary families, especially poor working families, depends a great deal on how the government decides to react to changes in the economy, and often this reaction has a profound effect on racial outcomes.

In considering the effect of those political actions that may not be motivated by issues of race, I am reminded of economist James K. Galbraith's observation that what is unique about the 1950s and 60s is that the government's policies -- social as well as economic -- were integral to the gains experienced by all families. Low-wage workers benefited from a wide range of protections, including steady increases in the minimum wage, and the government made full employment a high priority. Throughout the 1960s these policies were accompanied by federal wage-price guidelines that helped check inflation. In addition, a strong union movement emerged in the 1950s and 1960s following the passage of protective legislation in the 30s and 40s. The activities of unions ensured higher wages and more non-wage benefits for ordinary workers. 
In the 1970s and '80s things, however, moved in a different direction for lowwage workers. The union movement began its downward spiral, wage-price guidelines were eventually dropped, and macroeconomic policy was no longer geared toward tight labor markets. Monetary policy came to dominate public policy thinking on the economy, and it was focused on defeating inflation above all else.

The election of Ronald Reagan in 1980 brought to the federal government a new focus on the economy — one in which "supply-side economics" predicted that wealth for the few would eventually "trickle down" as financial well-being for all. As part of the Reagan experiment, the tax structure became more regressive; that is, the proportion of income taxes paid by the wealthy declined while the tax burden was dispersed through a number of other vehicles, including higher Social Security taxes. Furthermore, congressional resistance to raising the minimum wage and to expanding the Earned Income Tax Credit threatened the economic security of disadvantaged families.

During Bill Clinton's eight years in office, redistribution measures were taken to increase the minimum wage. But the George W. Bush administration halted increases in the minimum wage for nearly a decade, until the Democrats regained control of Congress in 2006 and voted to again increase the minimum wage in 2007. All of these political acts contributed to the decline in real wages experienced by the working poor. Because people of color are disproportionately represented among the working poor, these political acts have reinforced their position in the bottom rungs of the racial stratification ladder. In short, in terms of structural factors that contribute to racial inequality, there are indeed nonracial political forces that definitely have to be taken into account. 


\section{Understanding the Impact of Cultural Forces}

In addition to racial and nonracial structural forces, cultural forces may also contribute to or reinforce racial inequality. Two types of cultural forces are in play: (1) national views and beliefs on race and (2) cultural traits — shared outlooks, modes of behavior, traditions, belief systems, worldviews, values, skills, preferences, styles of self-presentation, etiquette, and linguistic patterns - that emerge from patterns of intra-group interaction in settings created by discrimination and segregation and that reflect collective experiences within those settings.

I want to avoid limited conceptions of culture defined in the simple and traditional terms of group norms, values, and attitudes toward family and work, and also consider cultural repertoires (habits, styles and skills) and the micro-level processes of meaningmaking and decision-making - that is, the way that individuals in particular groups, communities or societies develop an understanding of how the world works and make decisions based on that understanding. ${ }^{22}$ The processes of meaning making and decision making are reflected in cultural frames (shared group constructions of reality.)

Racism has historically been one of the most prominent American cultural frames and has played a major role in determining how whites perceive and act toward blacks. At its core, racism is an ideology of racial domination with two key features: (1) beliefs that one race is either biologically or culturally inferior to another and (2) the use of such beliefs to rationalize or prescribe the way that the "inferior" race should be treated in this society as well as to explain their social position as a group and their collective accomplishments. In the United States today, there is no question that the more categorical forms of racist ideology — in particular, those that assert the biogenetic inferiority of blacks - have declined significantly, even though they still may be 
embedded in institutional norms and practices. For example, school tracking, the practice of grouping students of similar capability for instruction, not only tends to segregate African American students but often results in placing some black students in lower level classes, even though they have the cultural capital—requisite skills for learning — to compete with students in higher level classes. ${ }^{23}$

However, there has emerged a form of what Lawrence Bobo and his colleagues refer to as "laissez faire racism," a perception that blacks are responsible for their own economic predicament and therefore undeserving of special government support. ${ }^{24}$ The idea that the federal government "has a special obligation to help improve the living standards of blacks" because they "have been discriminated against for so long" was supported by only one in five whites in 2001, and has never exceeded support by more than one in four since 1975. Significantly, the lack of white support for this idea is not related to background factors such as level of education and age.

The vast majority of social scientists agree that as a national cultural frame, racism, in its various forms has had harmful effects on African Americans as a group. Indeed, considerable research has been devoted to the effects of racism in American society. However, there is little research and far less awareness of the impact of emerging cultural frames in the inner city on the social and economic outcomes of poor blacks. Note that distinct cultural frames in the inner city that have not only been shaped by race and poverty, but in turn often shape responses to poverty, including, as we shall soon see, responses that may contribute to the perpetuation of poverty. Moreover, an important research question for social scientist is the following: how much of the framing of racial beliefs at the national level is based on the actual observed cultural traits among 
the inner-city poor and how much of it is the result of biased media reports and racial stereotypes.

In my own earlier work, I have discussed at length how several factors determine the extent to which communities, as areas bounded by place, differ in outlook and behavior. ${ }^{25}$ These factors include the degree to which the community is socially isolated from the broader society; the material assets or resources controlled by members of the community; the benefits and privileges the community members derive from these resources; their accumulated cultural experiences from current as well as historical, political, and economic arrangements; and the influence members of the community wield because of these arrangements.

Culture is closely intertwined with social relations in the sense of providing tools (skills, habits and styles) and creating constraints (restrictions or limits on behavior or outlooks) in patterns of social interaction. ${ }^{26}$ These constraints include cultural frames (shared visions of human behavior) developed over time through the processes of ingroup meaning making (shared views on how the world works) and decision making (choices that reflect shared definitions of how the world works) - for example, in the inner-city ghetto cultural frames define issues of trust/street smarts and "acting black" or "acting white" - that lead to observable group characteristics. ${ }^{27}$

One of the effects of living in racially segregated neighborhoods is exposure to group-specific cultural traits (cultural frames, orientations, habits, and worldviews as well as styles of behavior and particular skills) that emerged from patterns of racial exclusion and that may not be conducive to factors that facilitate social mobility. For example, as revealed in Elijah Anderson's research, some groups in the inner city put a high value on 
"street smarts," the behaviors and actions that keep them safe in areas of high crime. ${ }^{28}$ Street smarts may be an adaptation to living in unsafe neighborhoods. In this environment, it is wise to avoid eye contact with strangers and keep to yourself. This mind-set may also lead someone to approach new situations with a certain level of skepticism or mistrust. Although such an approach is logical and smart in an unsafe neighborhood, the same behavior can be interpreted as antisocial in another setting. Moreover, this street-smart behavior may, in some cases, prevent individuals from performing well on a job interview creating a perception that that they are not desirable job candidates.

Other concrete examples from the writings of both Elijah Anderson and Sudhir Venkatesh on the ghetto experiences might prove to be even more illuminating. ${ }^{29}$ Each author reveals the existence of informal rules in the inner-city ghetto that govern interactions and shape how people engage one another and make decisions. This decision making is influenced partly by how people come to view their world over time- - what we call "meaning making." It is important to remember that the process of meaning making and decision making evolve in situations impose by poverty and racial segregationsituations that place severe constraints on social mobility. Over time, these processes lead to the development of informal codes that regulate behavior.

First of all, Anderson talks about the "code of the street," an informal but explicit set of rules developed to govern interpersonal public behavior and regulate violence in Philadelphia's inner-city ghetto neighborhoods, where crime is high and police protection is low. Anderson argues that the issue of respect is at the root of the code. In a context of limited opportunities for self-actualization and success, some individuals in the 
community, most notably young black males, devise alternative ways to gain respect that emphasizes manly pride, ranging from simply wearing brand-name clothing to have the "right look," and talking the right way, to developing a predatory attitude toward neighbors. Anderson points out, however, that no one residing in these troubled neighborhoods is unaffected by the code of the street—especially young people, who are drawn into this negative culture both on the streets and in the schools as they must frequently adopt "street" behavior as a form of self defense. As Anderson puts it, "the code of the street is actually a cultural adaptation to a profound lack of faith in the police and the judicial system — and in others who would champion one's personal security." 30

A related informal but regulated pattern of behavior was described by Sudhir Venkatesh in his study of the underground economy in ghetto neighborhoods. Venkatesh points out that "the underground arena is not simply a place to buy goods and services. It is also a field of social relationships that enable off-the-books trading to occur in an ordered and predictable manner." 31 This trading often results in disagreements or breaches because there are no laws on the books, "but the main point is that in situations ostensibly criminal and often threatening to personal security, there is still a structure in place that shapes how people make decisions and engage one another." ${ }^{\text {,2 }}$ In other words, informal rules actually govern what would appear on the surface to be random underground activity. These rules stipulate what is expected of those involved in these informal exchanges and where they should meet. Just as Anderson describes a "code of the street", Venkatesh talks about a "code of shady dealings."

Like Anderson in his effort to explain the emergence of the code of the street, Venkatesh argues that the code of shady dealing is a response to circumstances in inner- 
city ghetto neighborhoods, where joblessness is high and opportunities for advancement are severely limited. Furthermore, both Anderson and Venkatesh clearly argue that these cultural codes ultimately hinder integration into the boarder society and are therefore dysfunctional. In other words, they contribute to the perpetuation of poverty.

Anderson finds that for some young men the draw of the street is so powerful that they cannot avail themselves of legitimate employment opportunities when they become available. Likewise, Venkatesh maintains that adherence to the code of shady dealings impedes social mobility. The "underground economy enables people to survive but can lead to alienation from the wider world" he states. ${ }^{33}$ For example, none of the work experience accrued in the informal economy can be listed on resume for job searches in the formal labor market, and time invested in underground work reduces time devoted to accumulating skills or contacts for legitimate employment.

However, many liberal scholars are reluctant to discuss or research the role that culture plays in the negative outcomes found in the inner city. It is possible that they fear being criticized for reinforcing the popular view that the negative social outcomespoverty, unemployment, drug addition, crime - of many poor people in the inner city are due to the shortcomings of the people themselves. Indeed, the Harvard University sociologist Orlando Patterson maintains that there is "a deep-seated dogma that has prevailed in social science and policy circles since the mid-1960s: the rejection of any explanation that invokes a group's cultural attributes: its distinctive attitudes, values and tendencies, and the resulting behavior of its members - and the relentless preference for relying on structural factors like low incomes, joblessness, poor schools and bad housing."34 
Patterson claims that social scientists have shied away from cultural explanations of race and poverty because of the widespread belief that such explanations are tantamount to blaming the victim; that is, they support the conclusion that the poor themselves, and not the social environment, are responsible for their own poverty and negative social outcomes. He colorfully contends that it is "utterly bogus" to argue, as do by many academics, that cultural explanations necessarily blame the victim for poor social outcomes. To hold an individual responsible for his behavior is not to rule out any consideration of the environmental factors that may have evoked the questionable behavior to begin with. "Many victims of child abuse end up behaving in self-destructive ways," Patterson states, "to point out the link between their behavior and the destructive acts is in no way to deny the causal role of their earlier victimization and the need to address it." ${ }^{35}$ Patterson also contends that a cultural explanation of human behavior not only examines the immediate relationship between attitudes and behavior but also looks at the past to investigate the origins and changing nature of these attitudes.

I agree with Patterson that cultural explanations should be part of any attempt to fully account for such behavior and outcomes. And I think it is equally important to acknowledge that recognizing the important role of cultural influences in creating different racial group outcomes does not require us to ignore or play down the role of structural factors.

The relative importance of cultural or structural explanations in accounting for behaviors and social outcomes is often debatable - though I have shown in More than Just Race (2009) that in terms of major effects on immediate group social outcomes and racial stratification, structure clearly trumps culture. ${ }^{36}$ Nevertheless, I firmly 
believe that to apply these explanations totally separately, without any attempt to show how they interact, is indeed a mistake. Moreover, if we are going to examine social and economic factors that, overtime, contributed to the development of certain cultural traits and related behavior, we must also pay serious attention to the immediate impact of structural conditions.

I also strongly agree with Orlando Patterson that an adequate explanation of cultural attributes in the black community must explore the origins and changing nature of attitudes and practices going back decades, even centuries. Unfortunately such analyses are complex and difficult. ${ }^{37}$ It took years of research by Kathryn Neckerman to provide the historical evidence to explain why so many black youngsters and their parents lose faith in the public schools. She shows in her book, Schools Betrayed, that a century ago, when African American children in most northern cities attended schools alongside white children, the problems commonly associated with inner-city schoolslow achievement and dropping out—were not nearly as pervasive as they are today. ${ }^{38}$

Neckerman carefully documents how city officials responded to increases in the African American student population: by introducing and enforcing segregation between black and white children in the city schools. And she discusses at length how poor white immigrant children — whose family circumstances were at least as impoverished as their black counterparts - received more and better resources for their education. Over the course of sixty years, then, generations of children of black Chicagoans were denied the opportunities that their white counterparts were able to expect from the public school system. 
Although most people today understand the suppression of black aspiration that occurred in the Jim Crow South, few realize that this tradition of school segregation persisted in northern cities, as Neckerman's book so aptly documents. "The roots of classroom alienation, antagonism, and disorder can be found in school policy decisions made long before the problems of inner-city schools attracted public attention," states Neckerman. "These policies struck at the foundations of authority and engagement, making it much more difficult for inner-city teachers to gain student cooperation in learning. The district's history of segregation and inequality undermined the schools' legitimacy in the eyes of its black students; as a result, inner-city teachers struggled to gain cooperation from children and parents, who had little reason to trust the school."39 Clearly, we can more fully understand the frustration and current cultural dynamics in inner-city neighborhood, in this case with reference to public schools, if we understand the history that work like Neckerman's uncovers.

Finally, altough culture "partly determines behavior, it also enables people to change behavior." ${ }^{40}$ Culture provides a frame for individuals to understand their world. And I agree that by ignoring or only investigating culture at a superficial level, social scientists miss an opportunity to help people understand and then reframe attitudes in a way that promotes desirable behavior and outcomes. ${ }^{41}$

However, attitudes must be reframed in conjunction with programs that address structural inequities. For example, take the problem of black male fatherhood. I would argue that programs focusing on the cultural problems pertaining to fatherhood, including attitudes concerning paternity, without confronting the broader and more fundamental issues of restricted economic opportunities have limited chances to succeed. In my view 
the most effective fatherhood programs in the inner city will be those that address the framing of attitudes, norms and behaviors in combination with local and national attempts to improve job prospects. Only when black fathers have a realistic opportunity to adequately care for their children financially will they be able to envision a more family-centered life for themselves and their children.

\section{Conclusion}

For many years social scientists and other observers and analysts have debated the role of social structure versus culture in explaining the social and economic outcomes of African Americans, including their educational attainment and success in the labor market. The position that one takes often reflects ideological bias. Conservatives tend to emphasize cultural factors whereas liberals pay more attention to structural conditions, with most of the attention devoted to racialist structural factors such as discrimination and segregation.

In this paper I develop a framework for understanding the formation and maintenance of racial inequality and racial group outcomes that integrates cultural factors with two types of structural forces - those that directly reflect explicit racial bias and those that do not. The longstanding problem of race in the United States calls for a bold, new perspective. Hopefully, this framework is a step in that direction. 


\section{Endnotes}

${ }^{1}$ I first discussed the concepts of indirect and direct forces of racial inequality in my contribution to a co-authored introduction to the volume 1 of America Becoming: Racial Trends and Their Consequences. Neil J. Smelser, William Julius Wilson, and Faith Mitchell, editors, Washington, D.C.: National Academy Press, 1-20.

${ }^{2}$ Vivian Henderson, "Race, Economics, and Public Policy," Crisis 83 (Fall 1975), 50-55.

${ }^{3}$ Ray Marshall. "School-to-Work Processes in the United States." (Paper presented at the Carnegie Corporation/Johann Jacobs Foundation, November 3-5, 1994, Marbach Castle, Germany).

${ }^{4}$ Based on an analysis of microdata - the integrated Public Use Microdata Series (IPUMS)—from Current Population Survey (1962, 1970, 1980, 1990), as well as published data in the U.S. Bureau of Labor Statistics. Employment and Earnings, 48, no. 1 (2001), and 54, no.1 (2007).

${ }^{5}$ Sylvia Nasar, "The Men in Prime of Life Spend Less Time Working." New York Times, December 1, 1994; and Stephen J. Rose "On Shaky Ground: Rising Fears About Incomes and Earnings." Research Report No. 94-02 (Washington, DC National Commission for Employment Policy, October 1994). Employment Policy.

${ }^{6}$ U.S. Bureau of the Census. Computer Use in the United States: October 1984, Current Population Reports, Series P-23, No. 155 (Washington, DC: U.S. Government Printing Office 1988), Table 4; and U.S. Bureau of the Census, Computer Use in the 
United States: 2003, Current Population Reports, Series P-23, No. 208, Washington, DC: U.S. Government Printing Office, 2003), Table D.

${ }^{7}$ Alan B. Krueger, "How Computers have Changed the Wage Structure: Evidence from Micro data, 1984-1989” Quarterly Journal of Economics, February 1993, 32-60.

${ }^{8}$ Alan B. Krueger, “What's Up With Wages?' (Princeton, NJ: Mimeo, Industrial Relations Section, Princeton University, Princeton, New Jersey, 1997; Lawrence Katz, Wage Subsidies for the Disadvantaged. National Bureau of Economic Research, Inc., Cambridge, MA, Working Paper 5679; and David Schwartzman, Black Unemployment: Part of Unskilled Unemployment. Westport CT: Greenwood Press, 1997.

${ }^{9}$ Schwartzman, op. cit.

10 James K. Galbraith, Created Unequal: The Crisis in American Pay. (New York: The Free Press, 1998), 9.

${ }^{11}$ Schwartzman, Black Unemployment. As Alan Krueger has remarked, "Whatever the role that trade has played in the past, I suspect that trade will place greater pressure on lowskilled workers in the future. The reason for this suspicion is simply that there are a great many unskilled workers in the world who are paid very little. One and a half billion potential workers have left schools before they reached age 13; half the world's workers leave at age 16 or earlier. When these workers are brought into global economic competition (because of greater openness, more political stability, and greater investment in developing countries), the consequences are unlikely to be positive for low-skilled workers in developed countries." Krueger, What's Up with Wages?. 
12 See, Stanley Lieberson, A Piece of the Pie: Black and White Immigrants Since 1880 (Berkeley: University of California Press, 1980); and Kathryn Neckerman, Schools Betrayed (Chicago: University of Chicago Press, 2007).

13 Schwartzman, op. cit.

${ }^{14}$ William Julius Wilson, The Truly Disadvantaged: The Inner City, The Underclass, and Public Policy (Chicago: University of Chicago Press, 1987); and William Julius Wilson, When Work Disappears: The World of the New Urban Poor (New York: Alfred A. Knopf, 1996).

${ }^{15}$ U.S. Department of Housing and Urban Development. The State of Cities (Washington, D.C.: Government Printing Office, 1999).

${ }^{16}$ Wilson, When Work Disappears, 1996.

${ }^{17}$ U. S. Department of Housing and Urban Development, State of Cities.

${ }^{18} \mathrm{~A}$ more detailed account of the transportation and networking problems of poor black workers is provided in William Julius Wilson, When Work Disappears.

${ }^{19}$ See, Frank Levy, The New Dollars and Dreams: American Incomes and Economic Change (New York: Russell Sage Foundation, 1998).

${ }^{20}$ According to sociologists Bruce Western Becky Pettit the recorded employment gains of low-skilled black men during the economic boom period of the 1990s were the artifact of the major expansion of mass black imprisonment during this period, And, according to their analysis, if the numbers of incarcerated blacks were added to the official employment statistics, the gains would disappear. Bruce Western and Becky Pettit, "Incarceration and Racial Inequality in Men's employment," Industrial and Labor Relations Review 54 (2000), 3-16. However, this position has been challenged 
by University of Wisconsin sociologist Felix Elwert, whose formal quantitative model suggests the opposite conclusion: that incarceration has likely increased rather than decreased low-skilled black unemployment rates. Felix Elwert, "The Effects of Incarceration on Aggregate Unemployment Rates (Unpublished manuscript, University of Wisconsin, 2008).

${ }^{21}$ In 2007 a single person with an annual income of $\$ 9,800$ and a family of four with an annual income of $\$ 33,600$ were classified as poor.

${ }^{22}$ My discussion in this section on the concept of 'culture' owes a great deal to the work of Michèle Lamont and Mario Luis Small. See Lamont and Small, "How Culture Matters for the Understanding of Poverty: Enriching Our Understanding," in The Color of Poverty: Why Racial and Ethnic Disparities Exist," eds by David Harris and Ann Lin. (New York: Russell Sage Foundation, 2008).

${ }^{23}$ For a review of the literature on school tracking, see Janese Free, "Race and School Tracking: From A Social Psychological Perspective," (paper presented at the annual meeting of the American Sociological Association, San Francisco, CA, August 14, 2004).

${ }^{24}$ Lawrence Bobo, James R. Kluegel, and Ryan A. Smith, "Laisse Faire Racism: The Crystallization of a Kinder, Gentler, Antiblack Ideology.” In Racial Attitudes in the 1990s, eds. Steven A. Tuch and Jack K. Martin. (Westport, Conn.: Praeger, 1997), 1544.

${ }^{25}$ Wilson, When Work Disappears.

${ }^{26}$ Charles Tilly, Durable Inequality (Berkeley CA: University of California Press, 1988). 
27 There is mixed evidence for the outcomes of "acting white" as it applies to education. One of the most well-known studies of this concept was published by Signithia Fordham and John Ogbu in 1986. They studied African American students at a high school in Washington D.C. and concluded that the fear of acting white was one of the major factors undermining student achievement. Signithia Fordham and John Ogbu, “Black Students' School Success: Coping with the 'Burden of 'Acting White,"” Urban Journal, 18 (1986, 176-206. In condtrast, Prudence Carter's studies have not supported the idea that students who avoided "acting white" held lower educational aspirations Prudence L. Carter, “'Black’ Cultural Capital, Status Positioning, and Schooling Conflicts for Low-Income African American Youth.” Social Problems, 50 (2003), 136155. and Keepin' It Real: School Success Beyond Black and White. (New York: Oxford University Press, 2005). Roland Fryer presents yet another perspective. He found that a high Grade Point Average (GPA) presents a social disadvantage for Hispanics and blacks in integrated schools and public schools, but he saw no such effect in schools that were segregated (80 percent or more black) or private. He also noticed a marked difference in this effect among black boys and black girls; black boys in public, integrated schools were particularly susceptible to social ostracism as their GPAs increased, and were penalized seven times more than black students (including both genders) overall (Roland G. Fryer, “'Acting White:' The Social Price Paid by the Best and Brightest Minority Students," Education Next, Winter 2006, 53-59.

${ }^{28}$ Elijah Anderson, Code of the Street: Decency, Violence, and the Moral Life of the Inner City (New York: W.W. Norton, 1999). 
${ }^{29}$ Sudhir Alladi Venkatesh, Off the Books: The Underground Economy of the Urban Poor (Cambridge: Harvard University Press, 2006).

${ }^{30}$ Anderson, Code of the Street, 34.

31 Venkatesh, Off the Books, 381.

32 Ibid, 377.

33 Ibid., p. 385. For another excellent study of how activities in the underground economy can adversely affect inner-city residents, see Loic Wacquant, "Inside the Zone: The Art of the Hustler in the Black American Ghetto," Theory, Culture, and Society 15 (1998), 1-36.

34 Orlando Patterson, “A Poverty of the Mind,” New York Times, March 26, 2006, Section 4, p. 13.

35 Ibid.

${ }^{36}$ William Julius Wilson, More than Just Race: Being Black and Poor in the Inner City. New York: W.W. Norton, 2009.

${ }^{37}$ Ibid. Also see Orlando Patterson, Taking Culture Seriously: A Framework and an Afro-American Illustration. In Culture Matters: How Values Shape Human Progress, eds. Lawrence E. Harrison and Samuel P. Huntington (New York: Basic Books), 202-18

${ }^{38}$ Neckerman, Schools Betrayed.

39 Ibid., p. 174.

40 Patterson, "Poverty of Mind," 13.

41 Ibid. 


\section{Bibliography}

Anderson, Elijah.. 1999. Code of the Street: Decency, Violence, and the Moral Life of the Inner City. New York: W.W. Norton, 1999; paperback 2000.

Bobo, Lawrence, James R. Kluegel, and Ryan A. Smith. 1997 “Laisse Faire Racism: The Crystallization of a Kinder, Gentler, Antiblack Ideology." In Racial Attitudes in the 1990s. Ed. Steven A. Tuch and Jack K. Martin. Westport, Conn.: Praeger.

Carter, Prudence L. 2003. “'Black' Cultural Capital, Status Positioning, and Schooling Conflicts for Low-Income African American Youth." Social Problems, 50(1): $136-155$. 2005. Keepin' It Real: School Success Beyond Black and

White. New York: Oxford University Press.

Elwert, Felix. 2008. "The Effects of Incarceration on Aggregate Unemployment Rates," Unpublished manuscript, University of Wisconsin.

Fordham, Signithia and John Ogbu. 1986. “Black Students' School Success:

Coping with the 'Burden of 'Acting White'." Urban Journal, 18(3):176-206.

Free, Janese. "Race and School Tracking: From A Social Psychological

Perspective," Paper presented at the annual meeting of the American Sociological Association, San Francisco, CA, August 14, 2004.

Fryer, Roland G. 2006. "'Acting White:' The Social Price Paid by the Best and Brightest Minority Students.” Education Next, Winter 2006: 53-59.

Galbraith, James K. 1998. Created Unequal: The Crisis in American Pay. New York: Free Press. 
Henderson, Vivian. 1975. "Race, Economics, and Public Policy." Crisis 83 (Fall):50-55.

Krueger, Alan B. 1993. "How Computers Have Changed the Wage Structure: Evidence from Microdata, 1984-1989.” Quarterly Journal of Economics (February):32-60. . 1997. "What's Up With Wages?” Mimeo, Industrial Relations Section, Princeton University.

Lamont, Michèle, and Mario Luis Small. 2008 (forthcoming). "How Culture Matters for the Understanding of Poverty: Enriching Our Understanding," in The Color of Poverty: Why Racial and Ethnic Disparities Exist, eds. David Harris and Ann Lin. New York: Russell Sage Foundation.

Levy, Frank. 1998. The New Dollars and Dreams: American Incomes and Economic Change. New York: Russell Sage Foundation.

Lieberson, Stanley. A Piece of the Pie: Black and White Immigrants Since 1880. Berkeley: University of California Press, 1980.

Marshall, Ray. 1994. "School-to-Work Processes in the United States." Paper presented at the Carnegie Corporation/Johann Jacobs Foundation, November 3-5, Marbach Castle, Germany.

Nasar, Sylvia. 1994. "The Men in Prime of Life Spend Less Time Working." New York Times, December 1.

Neckerman, Kathryn. 2007. Schools Betrayed. Chicago: University of Chicago Press. 
Patterson, Orlando. 1973. "The Moral Crisis of the Black American.” The Public Interest 32 (Summer):43-69. . 2000. "Taking Culture Seriously: A Framework and an Afro-

American Illustration.” In Culture Matters: How Values Shape Human Progress, eds. Lawrence E. Harrison and Samuel P. Huntington, pp. 202-18. New York: Basic Books.

Rose, Stephen J. 1994. "On Shaky Ground: Rising Fears About Incomes and Earnings." Research Report No. 94-02. Washington, DC: National Commission for Employment Policy, October.

Schwartzman, David. Black Unemployment: Part of Unskilled Unemployment. Westport CT: Greenwood Press, 1997.

Smelser, Neil. J., William Julius Wilson, and Faith Mitchell, eds. 2001. America Becoming: Racial Trends and Their Consequences, vol. 1. Washington, DC: National Academy Press.

Tilly, Charles. 1998. Durable Inequality. Berkeley, CA: University of California Press.

Tobin, James. 1965. "On Improving the Economic Status of the Negro.” Daedalus 94:878-98.

U.S. Bureau of the Census. Current Population Survey. 1962, 1970, 1980, 1990. Integrated Public Use Microdata Series (IPUMS). .1988. “Computer Use in the United States: October 1984.” In Current Population Reports, series P-23, no. 155. Washington, DC: Government Printing Office. 
. 2003. "Computer Use in the United States: 2003.” In Current

Population Reports, series P-23, no. 208. Washington, DC: U.S. Government Printing Office.

U.S. Bureau of Labor Statistics. 2001. Employment and Earnings 48/1.

Washington, DC: U.S. Government Printing Office. . 2007. Employment and Earnings 54/1. Washington, DC: U.S.

Government Printing Office.

U.S. Department of Housing and Urban Development. 1999. The State of Cities. Washington, DC: Government Printing Office.

Venkatesh, Sudhir Alladi. Off the Books: The Underground Economy of the Urban Poor. Cambridge: Harvard University Press, 2006.

Wacquant, Loïc. 1998, "Inside the Zone: The Art of the Hustler in the Black American Ghetto," Theory, Culture, and Society 15, 1-36.

Western, Bruce and Becky Pettit. 2000. "Incarceration and Racial Inequality in Men's employment," Industrial and Labor Relations Review 54:3-16

Wilson, William Julius. 1987. The Truly Disadvantaged: The Inner City, the Underclass and Public Policy. Chicago: University of Chicago Press. 1996. When Work Disappears: The World of the New Urban Poor.

New York: Alfred A. Knopf. .2009. More than Just Race: Being Black and Poor in the Inner City. New York: W.W. Norton. 
